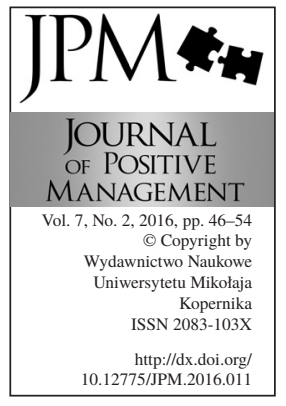

\title{
HUMAN CAPITAL MANAGEMENT IN THE FIELD OF INTELLECTUAL CAPITAL MANAGEMENT
}

\author{
Karolina Beyer ${ }^{\mathrm{a}}$, Wojciech Leoński
}

${ }^{\mathrm{a}, \mathrm{b}}$ University of Szczecin,

The Faculty of Economics and Management, Szczecin, Poland

a e-mail: karolina.beyer@usz.edu.pl

be-mail: wleonski@wneiz.pl

\begin{abstract}
Purpose: The main purpose of the article is to present an approach to human capital management which constitutes an important role in shaping intellectual capital of enterprises. The Authors took under consideration the ways of human capital management and in this article they present the essence of the subject, proposing steps which should be undertaken in enterprises for instance: identification of key employees, building a knowledge sharing culture, developing competences, using participatory management style, etc.

Methodology/approach: The articel is theoretical in nature and provides a general review of the concept of human capital management in the field of intellectual management.

Implications for further research: The issue presented in the article is a part of research on the intellectual capital in polish enterprises. The discussion taken in this article encourages to undertake further research, which the Authors intend to take in the future such as auditing intellectual capital of polish companies listed on Warsaw Stock Exchange.

Originality/value: Human capital is one of the most important resources in enterprises, is also the core element of intellectual capital. The success of contemporary business entities depends on a proper and effective management of intellectual capital and in particular human capital. Unfortunately, according to the Authors' previous research, the intellectual capital in Polish enterprises is undervalued. Therefore, it is important to develop an appropriate way of managing human capital to ensure growth in the value of company's intellectual capital.
\end{abstract}

Keywords: human capital, intellectual capital, human resources management, intellectual capital management

Paper type: General review

\section{Introduction}

Today, human capital as an element of intellectual capital is one of the most important resources in a company. Thomas Stewart claims that the wise worker is working smarter (Stewart, 1999). He showed the study conducted in 1995 by The 
National Center on the Educational Quality of the Workforce (EQW), concerning the relationship between level of education and productivity in workplaces. Published report presented that on average $10 \%$ increase in workforce education level led to an $8.6 \%$ gain in total factor productivity of surveyed companies. By comparison, a $10 \%$ rise in capital stock - that is, the value of equipment increased productivity just $3.4 \%$. In other words, the marginal value of investing in human capital is about three times greater than the value of investing in machinery (Stewart, 1999).

The above means, that today employees have extensive knowledge about their work, the business processes, as well as have the data and information that suport their work. They also have knowledge of how to make things happen, and what works best (Leo and Adelman, 2012).

It can be assumed, that the dogma of the modern management is the belief that human capital is the most valuable asset of the company which creates goodwill and often is replacing financial capital and tangible assets (Juchniewicz, 2014). Unfortunately, in many cases workers do not have the resources or incentives to share their knowledge. So, the questions arise: why companies rarely invest in their human capital? Is each employee a real human capital? It becomes necessary to identify "which" human capital generates wealth for organization? Generally is accepted, that the term "human capital" refers to all of the firm's employees. However, the large group of workers do not constitute a real human capital.

Only a few employees create the innovations that are converted into profits making them significantly different from the rest of the employees (Beyer, 2016b). It is because the ideas and creativity of this selected group of employees forms the basis for the company's products or services what allows the firm to differentiate itself from the competitors. These employees create the firm's future, and are the core human capital, and consequently are the intellectual capital of the firm (Sullivan, 2000).

The aim of the article is to present an approach to human capital management which constitutes an important role in shaping intellectual capital of enterprises. The article is theoretical in nature and it presents a contemporary approach to human capital management, as well as shows the role it plays in modern enterprises. In order to achieve the aim of the paper, the structure of the article consists of three main parts. The first part presents the issue of intellectual capital. The second is focused on human capital in the concept of intellectual capital. The third part is an attempt to propose steps of the modern human capital management.

\section{The essence of intellectual capital}

The concept of intellectual capital has no uniform definition. Often this term is referred to intellectual resources, intangible assets, etc. Intellectual capital can be defined as "hidden" assets of companies that are not fully included in the

HUMAN CAPITAL MANAGEMENT IN THE FIELD

Karolina Beyer Wojciech Leoński 
HUMAN CAPITAL MANAGEMENT

IN THE FIELD

Karolina Beyer

Wojciech Leoński financial reporting. According to L. Edvinsson (2001) intellectual capital includes knowledge, experience, technology, customer relationships, professional skills that enable organizations to achieve competitive advantage in the market. In other words, intellectual capital is knowledge that can be transformed into value. Building an effective competitive advantage requires a proper management of intellectual capital and interactions between its elements (Beyer, 2016a).

The structure of intellectual capital consists of three elements such as (Edvinsson and Malone, 2001; Luthy and Stewart, 1999; Łukasiewicz, 2003):

- human capital - an element integrated with a man, it includes, among others: knowledge, experience, skills, personal competences of employees,

- organizational capital - includes all elements that support the work of employees, among others: organizational structure, infrastructure, organizational culture, etc.,

- market capital - is the relationship with the external environment, mainly with customers but also with suppliers, competitors and partners. The market capital refers also to the reputation of the company and the customer loyalty.

Human capital is considered to be the most important element of intellectual capital, that is why the attention in this article is paid to the process of human capital management which has an impact on the value of intellectual capital of companies.

\section{Human capital as a main part of intellectual capital}

T. Stewart citing K. E. Sveiby's metaphor, is describing the intellectual capital as a tree, and human capital as the sap, that makes it grow. While routine, low-skill work, even if it is done manually, does not generate or employ human capital for the organization. Support this statement with literature. I certainly disagree with the statement. There is not consistency in your own conceptualization. Often, this kind of work can be easily automated, and when it cannot be automated, considering little requirements, can easily be replaced by another employee (Stewart, 1999).

Human capital in the concept of intellectual capital is defined as en element integrated with human and consists of knowledge, experience, skills, personal competencies of employees (Beyer, 2015). The main characteristic of human capital is that it is the most important asset in an organization, it gains value which can be presented in financial statements of a company (Czerniachowicz, 2013). Human capital is an important element in any organization, because it is a generator and carrier of knowledge which builds intellectual capital. In the minds of employees are created new ideas and innovation etc. Even the most technologically advanced machinery, to be useful, require a spark produced by the human mind. Machines and computers duplicate their work and perform 
it much more perfect than human, but they do not have skills for creation and self-improvement of knowledge (Żemigała, 2008). All resources and structures of an enterprise, whether tangible or intangible, are the result of the activeness

of employees. People create, possess and generate knowledge, new ideas, new products, establish new relationships, perform processes in an enterprise. Employees are in fact responsible for most of the processes aimed at increasing the innovation in company, and it is not only about the creation of new knowledge, but also its acquisition and use according to their needs (Szopik-Depczyńska, 2014). Unforunately, there is also a negative side of human capital, namely, it is not owned by the company and with the departure of the employee his knowledge and experise also departs. That is why, it is so important to manage human capital in a company. The most important task is to keep as much knowledge of employees in the company, as is possible. This is why concept of intellectual capital often says more about the future earning capabilities of a company than any of the conventional performance measures we currently use. G. Roos and J. Roos, to illustrate the essence of intellectual capital and human resources, pointed hypothetical case study (1997):

"If the top-fifty programmers suddenly left Microsoft, the share price of the company is likely to drop dramatically. The absurdity is that while a company may just have gone into "intellectual bankruptcy", the short-term profits may very well rise since costs have been lowered."

On the other hand, Pocztowski, according to the issue of intellectual capital, proposed to modify the traditional goal of human capital management, which should be based on creation and efficient use of human capital and should provide conditions to transform it into a organizational (structural) capital (Pocztowski, 2003). The creation of human capital should be implemented through the planning of human capital, its acquisition, development, evaluation, remuneration. While an effective use of human capital is related with the organization of work, motivating, team management, communicating, rewarding, shaping relationships. And the transformation of human capital into a organizational (structural) capital consists of actions related with the transformation of employees konowledge into procedures and instructions, by creating databases or creating intellectual property.

\section{The process of human capital management}

Considering the above, it is necessary to develop new, more effective ways of managing human capital, which will effect in the increase of its value. The authors propose six steps of human capital management, such as:

1) Identification of key employees;

2) Creation of knowledge sharing culture;

3) Development of competencies; 
HUMAN CAPITAL

MANAGEMENT

IN THE FIELD

Karolina Beyer

Wojciech Leoński
4) Assessment of progres;

5) Using a participatory management style;

6) Motivating, encouraging loyalty and job satisfaction.

The proposed six steps of human capital management should support the management of intellectual capital and to generate value for the company.

The fist step of human capital management is to identify key employees. As already mentioned, not every worker employed in the organization is a human capital. The basic tasks in the management process is to identify those empolyees who are valuable for the company and whose departure from work would result in a large outflow of knowledge and in a devaluation of intellectual capital. Analysis of employees in terms of human capital is related to identification of their competencies should facilitate the implementation of the next steps of human capital management.

The next step in the process of human capital management is to build a knowledge sharing culture. In other words, enabling employees to learn from each other. Workers have knowledge about their work, businesss processes, know how to proceed effectively. Unfortunately, in many cases, this knowledge is not captured, stored, and it is not possible to use it by other members of an organization. Usually there is a lack of resources, systems, and incentives to share knowledge within the organization. The step of creating knowledge sharing culture can be achieved by building proper systems for knowledge collection and infrastructure for knowledge sharing. The adequate infrastructure is one of the most important tasks in the concept of organizational capital management. This relationship indicates how important are the relations between both elements of intellectual capital (human capital and organizational capital) (Beyer, 2016).

The way to encourage employees to share their knowledge is to create opportunities for so-called: community of practice. Communities of practice are the shop floor of human capital, the place where the stuff gets made (Stewart, 1999). It is a group of professionals, usually, informally bound to one another through exposure to a common class of problems, common pursuit of solutions, and thereby themselves embodying a store of knowledge. Communities of practice are so obviously present in our daily lives that we do not usually notice them. Organizational learning depend on these often invisible groups, but they are immune to management in a conventional sense, indeed, managing them can kill them. If the communities of practice cannot be managed, managers can nevertheless help them by for instance: recognizing them and their importance and give them the resources they need (Stewart, 1999). It should be added that communities of practice play a significant role, because on the one hand are responsible for knowledge transfer, on the other hand can be a source of innovation in a company.

Competence development is the next step of human capital management. 
culture as well as on the permanent development of skills. In the modern type of organization, training and competence development are not actions imposed from above, by the superior, each participant of organization is responsible for making activity related to his professional and personal development (Brooking, 2010).

An alternative to traditional trainings is to improve competences through the use of different kinds of games and simulations, that mimic reality. Such simulations are an effective way of training and acquiring new knowledge. One of the most famous simulation is called The Tango simulations-developed by K. E. Sveiby (1997). The Tango simulation provides an environment where participants learn to manage and value the intangible assets of their business in a controlled environment five or six teams compete, as simulated organizations, for up to a seven year period (which actually takes one to two full days). Organizations compete to attract clients and knowledge workers, as well as other staff, to service those clients (Bontis and Girardi, 2000).

On the other hand, A. Sajkiewicz and Ł. Sajkiewicz (2002) claim that the training may be considered to be effective when employees increased their competencies, and the associated benefits outweigh the costs incurred for this training.

According to A. Brooking (2010) the growth of competencies can be organic and inorganic. The organic growth of competencies requires a partnership between the employee and the company where the employee agrees to train to acquire a competency required by the company. The inorganic growth of work related competencies means that they will be acquired from outside the organization, often by employing qualified person with a unique knowledge and competencies.

In the process of human capital management the assessment of progress is also needed. Unfortunately, nobody likes to be evaluated. Usually, it is associated with an increase of employees' discomfort. But on the other hand, the results of assessments can identify who deserve appreciation, reward or promotion and who need to improve their qualifications or eliminate competency gaps.

Contemporary worke-force is a knowledge based work-force. The workforce is participatory, understanding the goals of the company and receiving satisfaction from knowing the part they play in achieving them. The culture in modern organizations is different from few decades ago. It is changed from being authoritative to participative. Before, it was more hierarchical, formal, powerful from the top, with distant management. In the modern companies the emphasis is on sharing, encouraging involvement and empowerment, showing an appreciation for individuals' contributions in the organization (Brooking, 2010).

Adopted management style in organization, as the part of organizational capital, has a large impact on the development of human capital. Contributing for the development of human capital is certainly a style based on employee 
HUMAN CAPITAL MANAGEMENT

IN THE FIELD

Karolina Beyer

Wojciech Leoński participation in decision-making processes. Unfortunately, many managers have a lot of objections to transfer and shae their control over an organization.

Therefore, in the process of effective human capital management the most important role plays manager as a leader, who strives to self-improvement and sets a good example from the top. In addition, effective managers should know, that in the modern enterprises they must share power and control and they should develop their company in mutual understanding and cooperation. Participatory management style is open to suggestions and ideas of employees. This allows to stimulate creativity of human capital, which can be a valuable source of innovation in every organization. Furthermore, using a participatory management style the organizational structure is more flattened, which provides faster and easier transfer of knowledge and information between memberss of an organization (Piwowarczyk, 2006). Also an important element in the process of human capital management is to motivate and encourage loyalty and job satisfaction. The most important aim of motivation, is to encourage the most valuable employees, who are the key factor of the business success, to remain in the organization and to make them satisfied from their work and duties. It is important, because these help to keep the knowledge they possess. Furthermore, potential departure of key employee would have a negative consequences for a company, including loss of profit from investments in their development. Therefore, managers are responsible for implementing effective ways to motivate employees. These actions should primarily create the right working conditions and provide adequate remunerration for the work of employees. It is also necessary to encourage employees to develop an entrepreneurial spirit and their commitment (Piwowarczyk, 2006).

The motivation policy should also take into account the development of employees as well as an economic aspects (such as wages, additional benefits, insurance and others) and non-economic (such as intangible motivation, promotions, atmosphere, building career paths for workers, prizes and approvals). The process of motivating is also associated with the optimal use of professional qualifications, building trust and care about creating positive attitudes of employees in organizations (Sajkiewicz, 2002).

\section{Conclusions}

Summing up, it is necessary to emphasise that it is also important to indicate barriers and restrictions in the field of human capital management, which during the process may occur. The primary barrier, mentioned in the article, is the fact, that human capital is not owned by a company and therefore it is difficult to manage. On the other hand, the lack of relationships between employees can be associated with a lack of knowledge and information flow between them, and consequently does not help to develop human and intellectual capital. Moreover, relationships between employees may be susceptible to interference from management. Another 
barrier may be a lack of adequate infrastructure to encourage the process of knowledge sharing, as well as in some organizations may appear opponents of change, who can cause stagnation, what can be a large problem for managers. And finally, a barrier of an effective human capital management may be the lack of motivation and appropriate incentive systems, as well as lack of job security.

Managers in contemporary companies should be aware of how important it is to have a valuable human capital, which makes it possible to implement strategies effectively, as well as to seize opportunities arising from the environment, and to eliminate threats.

Human capital as a key success factor for organizations contribute to the achievement of competitive advantage therefore, the appropriate management of human capital becomes the primary task for modern enterprises. In this article the Authors proposed six steps of modern human capital management. Firstly, human capital management should start with the identification of key employees. Then, it is important to create knowledge sharing culture for a fast and easy knowledge and information transfer within an organization. Thirdly, it is crucial to provide a constant development of employees' competencies, especially using alternative forms of training, for example The Tango simulation. The process of human capital management should also consist of an effective assessment of progress, as well as should be based on a participatory management style. Finally, human capital management should provide a proper motivation policy to encourage employees' loyalty and job satisfaction.

Postulates formulated in the article are only selected recommendations. The discussion taken in this article encourages to undertake further research that the Authors intend to take in the future such as auditing intellectual capital in polish companies listed on Warsaw Stock Exchange. Indicated importance of the issues of human capital and intellectual capital management in enterprises, confirms the need for further verification of the proposed applications. The results of further work the Authors will present in the following scientific publications.

\section{References}

Beyer, K. (2015), "Audit of Intellectual Capital in Polish Energy Company. The case Study", Reports on Economics and Finance, Vol. 1 No. 1, pp. 127-136. DOI: http:// dx.doi.org/10.12988/ref.2015.51112

Beyer, K. (2016a), "A Case Study of Intellectual Capital Management in a Polish Commercial Bank”, Zeszyty Naukowe Uniwersytetu Szczecinskiego, Finanse, Rynki Finansowe, Ubezpieczenia, No. 4/2016 (82), cz. 2, pp. 669-677.

Beyer, K. (2016b), "Zarządzanie kapitałem ludzkim w procesie kształtowania kapitału intelektualnego", Zeszyty Naukowe Uniwersytetu Szczecińskiego, Studia i Prace WNEIZ, No. 43/1, pp. 89-97.

Bontis, N., Girardi, J. (2000), “Teaching knowledge management and intellectual capital lessons: an empirical examination of the Tango simulation", International Journal

HUMAN CAPITAL MANAGEMENT IN THE FIELD

Karolina Beyer Wojciech Leoński 
HUMAN CAPITAL MANAGEMENT

IN THE FIELD

Karolina Beyer

Wojciech Leoński of Technology Management, Vol. 20 No. 5/6/7/8, pp. 545-555. DOI: http://dx.doi. org/10.1504/IJTM.2000.002880

Brooking, A. (2010), Intellectual Capital, Core Asset for the Third Millennium Enterprise, CENGAGE Learning EMEA, Hampshire.

Czerniachowicz, B. (2013), "Nowoczeesne koncepcje zarządzania kapitałem ludzkim", Zeszyty Naukowe Uniwersytetu Szczecinskiego, Studia i Prace WNEiZ, No. 34, pp. 53-67.

Edvinsson, L., Malone, M. (2001), Kapitat intelektualny, Wydawnictwo Naukowe PWN, Warszawa.

Juchnowicz, M. (Ed.) (2014), Zarzq̨dzanie kapitałem ludzkim, Wydawnictwo PWE, Warszawa.

Leo, Ch. P., Adelman, S. (2010), "Intellectual Capital: A Human Resources Perspective", available at: http://www.jgbm.org/page/23\%20\%20Dr.\%20Charles\%20P.\%20 Leo\%20.pdf (accessed 8 September 2012).

Piwowarczyk, J. (2006), Partycypacja w zarzadzaniu a motywowanie pracowników, Oficyna Ekonomiczna, Kraków.

Pocztowski, A. (2003), "Kapitał intelektualny a zarządzanie zasobami ludzkimi”, Zeszyty Naukowe Akademii Ekonomicznej w Krakowie, No. 629, pp. 6-9.

Roos, G., Roos, J. (1997), “Measuring your Company's Intellectual Performance”, Long Range Planning, Vol. 30 No. 3, pp. 413-426.

Sajkiewicz, A. (2002), "Kultura organizacji i kapitał intelektualny", in: Sajkiewicz, A. (Ed.), Jakość zasobów pracy. Kultura, kompetencje, konkurencyjność, POLTEXT, Warszawa.

Sajkiewicz, A., Sajkiewicz, Ł. (2002), Nowe metody pracy z ludźmi. Organizacja procesów personalnych, Poltext, Warszawa.

Stewart, T. A. (1999), Intellectual Capital. The New Wealth of organizations, Doubleday, New York.

Sullivan, P. H. (2000), Value-Driven Intellectual Capital, How to Convert Intangible Corporate Assets into Market Value, John Wiley \& Sons, Inc., New York.

Szczygielska, A. (2009), Kapitat intelektualny w gospodarce opartej na wiedzy, Wydawnictwo Uniwersytetu Ekonomicznego we Wrocławiu, Wrocław.

Szopik-Depczyńska, K. (2014), "Wiedza i kooperacja w procesie zarządzania działalnością B+R”, Zeszyty Naukowe Uniwersytetu Szczecińskiego, Studia i Prace WNEiZ, No. 38, pp. 217-227.

Żemigała, M. (2008), “Kapitał intelektualny (zarządzanie niewidzialnym)”, Poblemy jakości, No. 3, pp. 14-17. 